\title{
A Case of Multiple Schwannoma That Originated in the Nasal Septum
}

\author{
Seung Wook Han, Jae Hong Aum, and Il Gyu Kang \\ Department of Otolaryngology-Head \& Neck Surgery, Gil Medical Center, Gachon University Medical School, Incheon, Korea
}

\section{비중격에서 기원한 다발성 신경초종 1 예}

한승욱 · 엄재홍 - 강일규

가천대학교 길병원 이비인후-두경부외과학교실

\author{
Received July 18, 2014 \\ Revised September 19, 2014 \\ Accepted September 24, 2014 \\ Address for correspondence \\ Il Gyu Kang, MD, PhD \\ Department of Otolaryngology- \\ Head \& Neck Surgery, \\ Gil Medical Center, \\ Gachon University Medical School, \\ 21 Namdong-daero 774beon-gil, \\ Namdong-gu, \\ Incheon 405-760, Korea \\ Tel $+82-32-460-3324$ \\ Fax $+82-32-467-9044$ \\ E-mail eyik@naver.com
}

Schwannomas are benign peripheral nerve sheath tumors that occur throughout the body. They may appear as either a solitary mass or multiple masses. A 76-year-old woman visited our clinic with swelling of her nasal tip. Initially, based on her medical history, physical examination and CT scan, we diagnosed the disease as a neurogenic tumor or metastatic carcinoma; however, the incisional biopsy result revealed schwannomas that had originated from the nasal septum. The two masses were completely resected using the external rhinoplasty approach. Multiple schwannomas that originate in the nasal septum are extremely rare, and we report herein with a review of literature. Korean J Otorhinolaryngol-Head Neck Surg 2015;58(6):425-8

Key Words Nasal septum $\cdot$ Schwannoma.

\section{서 론}

신경초종(schwannoma)은 말초신경집(pheripheral nerve sheath) 내 신경초세포(schwann cell)에서 기원하는 양성종 양이다. 신경초종의 약 25 45\%는 두경부의 신경조직에서 발 생하고 비강 및 부비동에서 발생하는 경우는 약 $4 \%$ 빈도로 드 문 것으로 알려져 있다.,2) 이 중 비강 내 특히 비중격 내에 발생 한 경우는 드물어 국내에서는 1 예 보고된 바 있으난) 다발성으 로 발생한 경우는 국내에서 보고된 바 없다. 본 저자들은 76세 여자 환자의 양측 비중격 내에서 발생한 다발성 신경초종 1예 를 치험하였기에 문헌고찰과 함께 보고하는 바이다.

\section{증 례}

76세의 여자 환자로 내원 20일 전 우연히 발견한 무통성의 비 첨부 종창을 주소로 내원하였다. 과거력상 고혈압 및 당뇨로
투약치료 중이며 약 20년 전 제2형 신경섬유종증을 진단받고 우측 청신경종 및 척추 결절종 수술을 시행 받았으며 내원 1년 전에는 좌측 유방암 진단 하에 수술을 시행 받은 바 있었다. 그 외 다른 전신질환의 과거력이나 가족력상 특이 소견은 없었 다. 이학적 검사상 비첨에서 양측 비강 내로 돌출된 약 $2 \mathrm{~cm}$ 크 기의 매끈한 표면의 낭성종물이 관찰되었으며(Fig. 1), 부비동 전산화단층촬영상 비첨에서 양측 비강에 걸쳐 $2 \times 2 \mathrm{~cm}$ 크기의 종물이 관찰되었으며, 종물 내에 중등도의 불균등한 조영증강 소견이 관찰되었다(Fig. 2). 이외 두개 내 전두엽 우하방 및 우내 측에 각각 $1 \mathrm{~cm}$ 및 $4 \mathrm{~cm}$ 크기의 종괴를 우연히 발견하였고 뇌 자기공명영상상 뇌수막종 의심 하에 경과 관찰하기로 하였다.

뇌자기공명영상상 비첨의 종괴는 두 개로 비중격에서 양측으 로 기원하고 있었으며 우측은 $1.8 \times 1.8 \mathrm{~cm}$ 좌측은 $0.8 \times 0.8 \mathrm{~cm}$ 였 으며 $\mathrm{T} 1$ 에서 저강도의 신호를 $\mathrm{T} 2$ 에서 고강도 및 중등도의 강 도의 신호가 혼재된 양상을 보이고 있었으며 주변조직과의 경계가 비교적 명확하였다(Fig. 3). 과거력 및 이학적 검사, 방사 


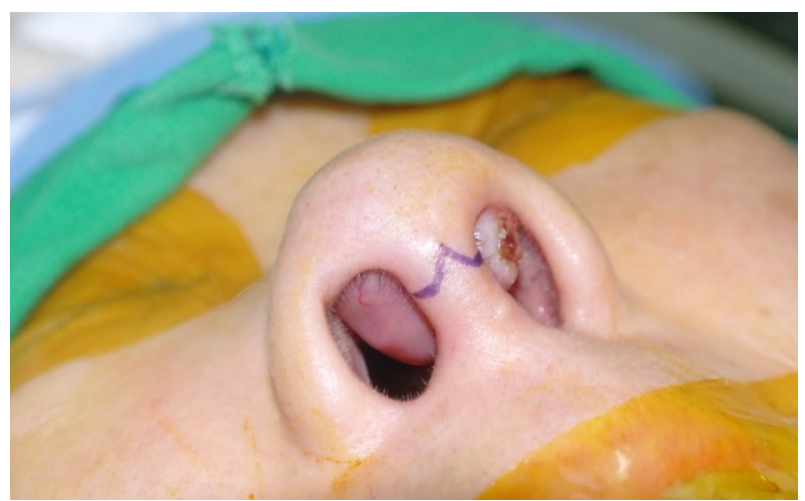

Fig. 1. Preoperative finding of a nasal mass: a cystic mass that filled the right and left nasal cavities.

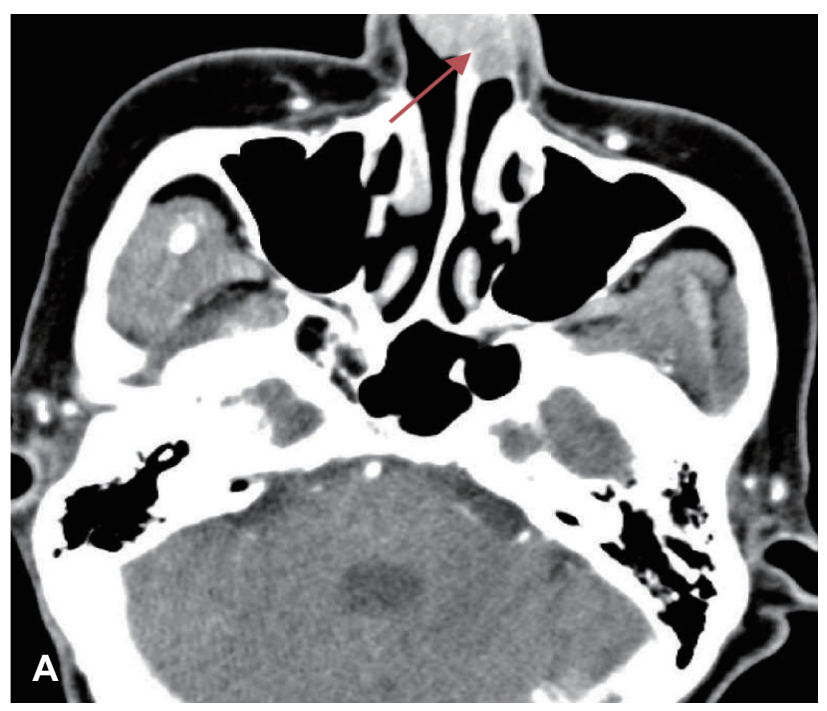

선학적 소견을 종합했을 때 신경종 또는 유방암 전이 의심 하 에 절개 생검을 통한 조직검사를 시행하였으며, 검사결과상 신 경초종이 진단되었다. 전신마취 하에 비외접근법을 통한 종물 절제술을 시행하였으며 비주에 inverted V incision을 통하여 접근하여 연부조직을 박리하여 비중격을 노출하였으며 비중 격 양측으로 유래한 종물을 확인하였다. 종물은 비중격 전벽 부 및 좌상부에 기원하였으며 각각 $2 \times 2 \mathrm{~cm}, 1 \times 1 \mathrm{~cm}$ 크기로 경계가 명확하고 피막에 둘러 쌓여 있었고 비교적 박리가 잘되 어 완전 절제하였다. 최종 조직검사에서 S-100 단백 면역 염색 상 양성 반응으로 이전 조직검사와 같은 신경초종에 합당한 소견 을 보였다(Fig. 5). 환자 현재 술 후 6개월째로 정기적인 외래 추

Fig. 2. PNS CT scan with contrast demonstrating about $2.0 \times 2.0 \mathrm{~cm}$-sized well-circumscribed, contrast-enhanced heterogeneous mass (arrow) lesions on the nasal tip (A: axial view, B: sagittal view).
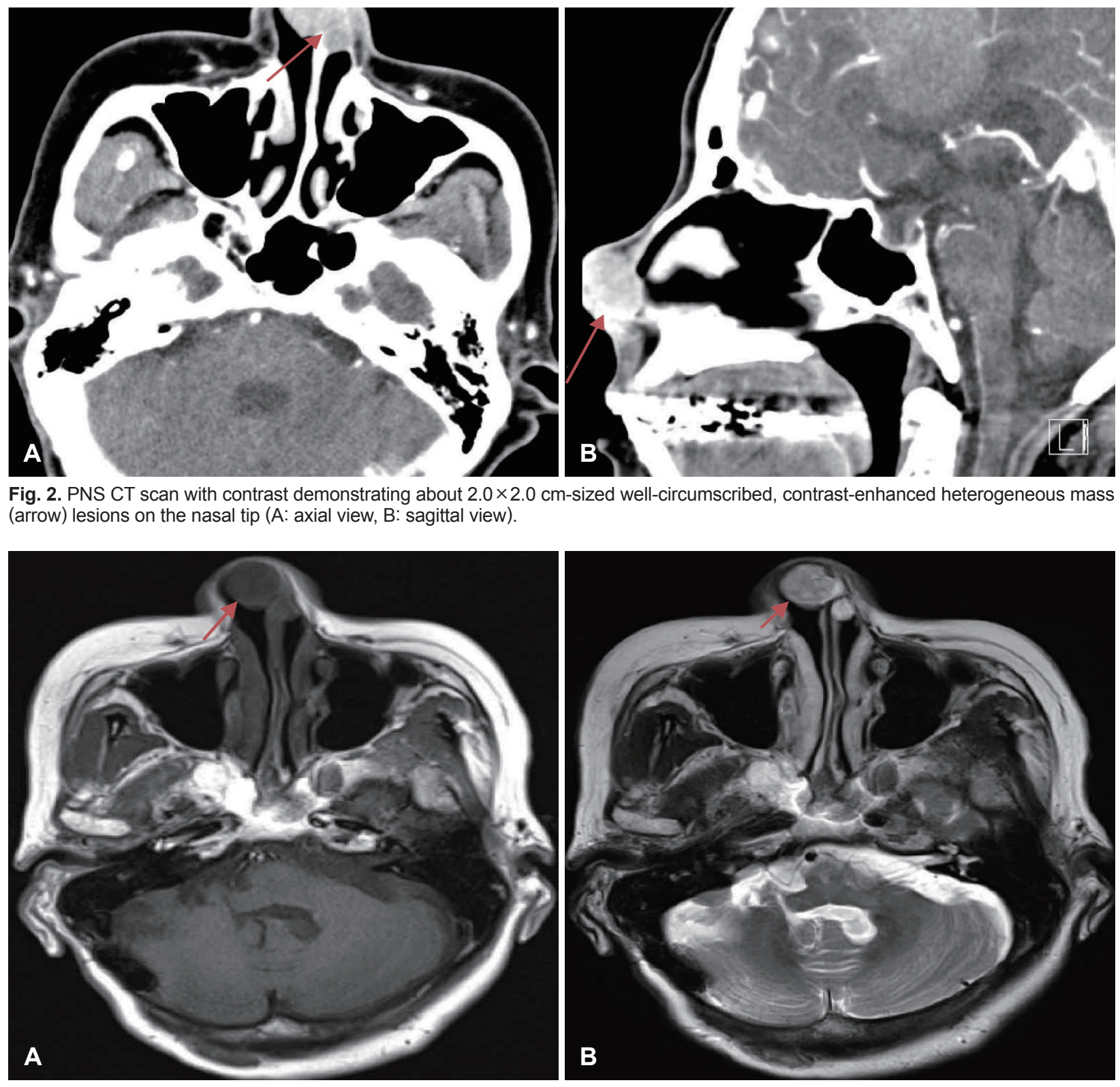

Fig. 3. Brain MR images showed double nasal tip masses (arrow) that originated in the septum and showed a low signal in the T1-weighted image (A), and a heterogeneous signal in the T2-weighted image (B). 

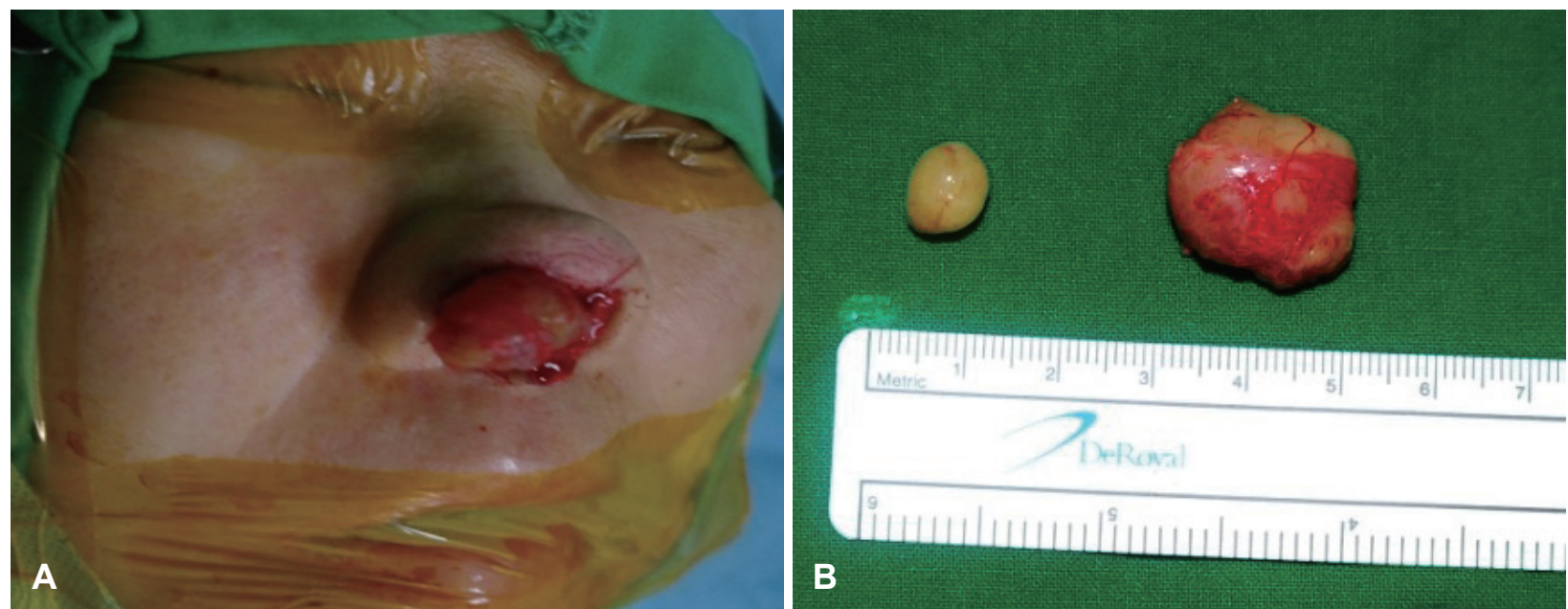

Fig. 4. Septal masses were removed using the external approach (A), and $2.3 \times 2.1 \times 1.6 \mathrm{~cm}$ and $0.8 \times 0.7 \times 0.5 \mathrm{~cm}$ well-encapsulated smoothsurface masses were resected from the nasal septum (B).
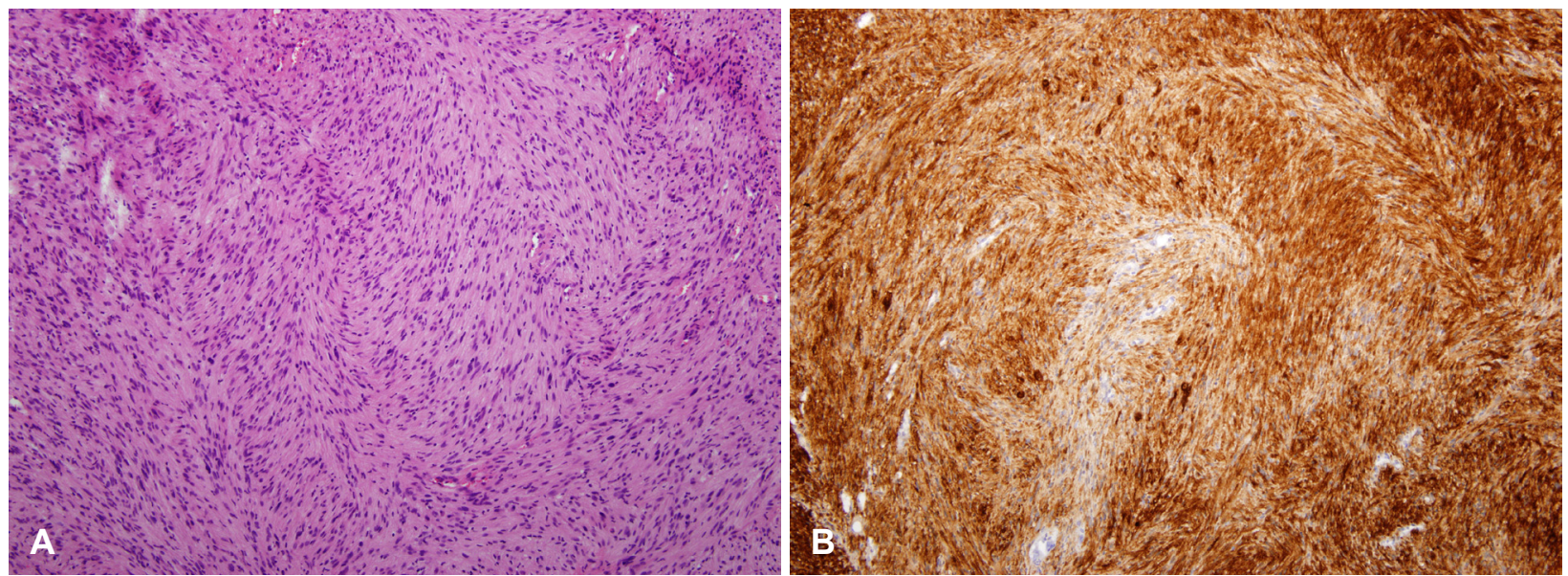

Fig. 5. Tumor composed of spindle cells with a pallisading arrangement $(H \& E$ stain, $\times 200)(A)$ and immunochemical stain showing a positive reaction to the S-100 protein $(S-100$ stain, $\times 200)(B)$.

적관찰 중이며, 재발 소견 없이 다른 증상은 호소하고 있지 않다.

\section{고 찰}

신경초종은 양성 신경집 종양으로 신경초세포가 있는 신 경이면 전신의 어디에서도 발생할 수 있다고 알려져 있다. ${ }^{4}$ 두 경부 영역에서는 8 번째 뇌신경인 전정신경에서 가장 많이 발 생한다고 알려져 있으며 이외에도 두피, 안면, 구강, 인두, 후두, 기관, 이하선, 중이 및 외이에서 발생 가능하다. ${ }^{5)}$ 두경부 영역 중 비강 및 부비동에서 발생하는 경우는 $4 \%$ 이내로 흔하지 않 은데 주로 사골동에서 기원하며 상악동 및 비강, 접형동이 빈 도수에서 그 뒤를 따른다.) 이 중 비중격 내에만 국한되어 발생 하는 경우는 드물어 전 세계적으로 지금까지 약 20예 정도만 이 보고되고 있다.8) 국내문헌에서는 비강 및 부비동 내 신경 초종으로 각각 14예, 4예 보고된 바 있으며 비중격에서 발생
한 경우는 1예가 보고된 바 있는데 종괴가 다발성으로 보인 경우는 보고된 바 없다.,3,9-12) 신경초종이 국소적으로 다발성으 로 생긴 경우 종양성 증후군(tumor predisposition syndrome) 인 제2형 신경섬유종증(neurofibromatosis type II) 및 신경초 종증(schwannomatosis)을 의심해 볼 수 있으며 증례의 경우 환 자의 기저질환인 제2형 신경섬유종증과 연관이 있다고 생각되 었다. ${ }^{13,14)}$

신경초종의 임상증상은 특이할만한 초기 증상은 없으며, 대 부분이 신경학적 증상 없이 무통성의 종괴를 보이다가 종물이 서서히 커지면서 주변 구조물들의 압박 효과로 비폐색, 비루, 통증, 안면부 종창, 후각이상, 비출혈, 종물에 의한 압박감 등 을 호소할 수 있으며, 3,89 본 증례의 경우 비첨에 생긴 종물로 인한 외비변형이 주 증상이었다. 이학적 검사상 피막에 잘 싸여 진 점액질 혹은 낭성의 비특이적인 용종상의 종물로 관찰되는 경우가 많으나 주목할만한 특징적인 소견은 보이지 않아 유피낭 
(dermoid cyst), 신경교종(glioma), 유표피종(epidermoid cyst), 연골종양(cartilaginous tumor) 등과 감별이 쉽지 않아 이학적 검 사로 확진은 불가하며 조직검사 결과만으로 진단이 가능하다.,8,9)

신경초종의 방사선학적 소견으로는 전산화단층촬영상 종물 내 주변의 낭성조직과 구분되는 고밀도의 조영증강을 보이는 것이 특징이며, 자기공명영상촬영상 $\mathrm{T} 1$ 에서 중등도의 신호, $\mathrm{T} 2$ 에서 다양한 신호 강도를 보이는 것이 특징이다. 그러나 이상의 소견 역시 비특이적으로 확진을 위해서는 조직학적 절제 및 생 검이 필요하다. ${ }^{3,8,9)}$

신경초종의 조직병리학적 소견은 S-100 단백면역염색에서 양성 반응을 보이고, $\mathrm{H \& E}$ 염색상에서 Antoni type A와 B가 혼재된 소견을 나타내는 것이 특징이다. Antoni A형은 신경초 세포가 주위 결합조직과 잘 배열되어 있고, 핵의 중앙에 verocay body가 존재하고 핵이 책상배열(palisading pattern)을 이룬 다. Antoni B형은 상대적으로 퇴행성의 변화와 함께 엉성한 형태의 조직 간질을 보이고 출혈성 괴사 또는 낭종성 변화를 동반하기도 한다. ${ }^{10)}$ 본 증례에서는 수술 후 조직검사에서 S-100 단백면역염색상 양성반응을 보인 방추세포의 증식과 $\mathrm{H} \& \mathrm{E}$ 염색상에서 Antoni type $\mathrm{A}$ 와 $\mathrm{B}$ 소견이 보여 신경초종 으로 진단할 수 있었다.

신경초종의 치료는 종괴가 방사선 치료에 저항성이 있으므 로 외과적 완전 적출이 원칙이다. ${ }^{11)}$ 수술적 제거 시 피막에 싸 인 채 적출해야 하나, 일부 피막이 남아 있어도 재발은 거의 하지 않는 것으로 보고되고 있다. ${ }^{12)}$ 비강 내 신경초종은 발생한 예가 많지 않아 진단과 치료방법이 아직 확실히 정립된 바 없다. 특히 비중격 내 발생한 경우 임상 증상 및 이학적 소견만으로 는 다른 질환과 감별이 쉽지 않기 때문에 주의를 요하며 병변 부위의 병리조직학적 검사와 함께 다양한 면역염색을 통해 진단하는 것이 중요하다. 절제를 위한 접근 방법은 종괴의 위 치와 범위에 따라 선택되는데 본 예처럼 종물이 코 끝까지 위 치한 경우 비외 접근법을 사용하면 충분한 종괴 노출 및 좋 은 미용적 결과를 얻을 수 있다. 예후는 대부분의 신경초종이
술 후 재발은 드문 편이며 악성변화는 거의 없는 것으로 알려 져 있으나 제2신경섬유종증과 같은 유전질환과 동반된 신경 초종의 경우 평생에 걸쳐 전신의 다른 부위에 새로운 신경초 종이 생길 가능성이 높으므로 정기적인 이학적 검사 및 신경학 적 평가가 필요하다. ${ }^{10,13,14)}$

\section{REFERENCES}

1) Choe H, Jun YJ, Cho WS, Kim TH. A case of schwannoma of the nasal cavity mimicking olfactory neuroblastoma. Korean J OtolaryngolHead Neck Surg 2007;50(6):548-51.

2) Berlucchi M, Piazza C, Blanzuoli L, Battaglia G, Nicolai P. Schwannoma of the nasal septum: a case report with review of the literature. Eur Arch Otorhinolaryngol 2000;257(7):402-5.

3) Jung SG, Han SY, Kim DE, Ahn BH. A case of schwannoma of the nasal septum. Korean J Otorhinolaryngol-Head Neck Surg 2010;53 (8):497-500

4) Pagella F, Giourgos G, Matti E, Colombo A. An asymptomatic schwannoma of the nasal septum: report of a unique case. Ear Nose Throat J 2009;88(12):1264-5.

5) Gulia JS, Yadav SS, Basur SK, Hooda A. Schwannoma of the membranous nasal septum. Braz J Otorhinolaryngol 2013;79(6):789.

6) Pauna HF, Carvalho GM, Guimarães AC, Maunsell RC, Sakano E. Schwannoma of the nasal septum: evaluation of unilateral nasal mass. Braz J Otorhinolaryngol 2013;79(3):403.

7) Tidmore T, Calhoun KH, Hirschi S, Miick R. Columellar schwannoma. Ear Nose Throat J 2009;88(10):E38-40.

8) Janardhanan S, Kulothungan K, Felix V. Schwannoma of the nasal septum-a case report. Online J Otolaryngol 2012;2(4):30-6.

9) Koh TK, Bae WY, Rha SH. A case of nasal schwannoma coexisting with epidermal cyst. Korean J Otorhinolaryngol-Head Neck Surg 2013; 56(12):787-90.

10) Park EH, Lee SS, Byun SW. A schwannoma in the nasal septum. Eur Arch Otorhinolaryngol 2008;265(8):983-5.

11) Jo JM, Kwon MH, Yi JO, Kim MJ. A case of schwannoma of the nasal tip: resection using an external rhinoplasty approach. Korean J Otolaryngol-Head Neck Surg 2011;54(5):356-9.

12) Seo YI, Nam SY, An KH, Kim SY, Lee KS. Extracranial nerve sheath tumors of the head and neck. Korean J Otolaryngol-Head Neck Surg 1997;40(6):908-13.

13) Butugan O, Schuster GS, de Almeida ER, Miniti A. Schwannoma of the nasal septum: report of two cases. Rev Laryngol Otol Rhino 1993; 114:33-6.

14) Asthagiri AR, Parry DM, Butman JA, Kim HJ, Tsilou ET, Zhuang Z, et al. Neurofibromatosis type 2. Lancet 2009;373(9679):1974-86. 